\title{
The notion of the moon in the calendar and religion of the Bulsa (Ghana)
}

\section{Franz Kröger}

\section{(2) OpenEdition \\ 12 Journals}

Electronic version

URL: http://journals.openedition.org/span/610

DOI: $10.4000 /$ span. 610

ISSN: 2268-1558

Publisher

École pratique des hautes études. Sciences humaines

\section{Printed version}

Date of publication: 1 September 1986

Number of pages: 149-151

ISSN: 0294-7080

\section{Electronic reference}

Franz Kröger, «The notion of the moon in the calendar and religion of the Bulsa (Ghana) », Systèmes de pensée en Afrique noire [Online], 7 | 1986, Online since 05 June 2013, connection on 06 May 2019. URL : http://journals.openedition.org/span/610 ; DOI : 10.4000/span.610 


\title{
THE NOTION OF THE MOON \\ IN THE CALENDAR AND RELIGION \\ OF THE BULSA (GHANA)
}

\author{
par \\ Franz Kröger
}

The alternation of 1 ight and darkness, marked by sunrise and sunset, and the regular succession of dry and wet seasons with its impact on agricultural activities are the basis for many ceremonies among the Bulsa of Northern Ghana. The moon, however, does not play a major role in their religious and ritual life, nor in their notion of time and their calendar.

This does not mean that Bulsa disregard the phases of the moon. They recognize the "birth of a new moon" and count its age in days. In their language, Buli, there are only a few terms for the different phases of the moon : kiik kum (death of a moon) for "waned moon", chi-bulik (young moon) and chi-paalik (new moon) for the first thin crescent of the waxing moon. More precise are the descriptions of lunar shapes in terms of age, e.g., chiika ta ka da pi jinla (today the moon is ten days old). Everybody can imagine the form of a moon at, say, eight or twenty days; and everybody knows that a fifteen-day old moon is a full moon.

The phases of the moon are used only rarely to denote a specific day in the near future. For short periods of time, the Bulsa use the market cycles of the various villages, e.g., "I will see you again on Wiaga market day". For longer spans of time, they may make use of seasonally or ritually outstanding events, e.g., "I will return after the early millet sacrifices". If there is no suitable event in the seasonal or ritual calendar, they may then switch to lunar measures. Thus, I was told that four months, or moons, after the harvest the field should be prepared for sowing; and it is also possible to say $m i$ le jam popo chiik, "I will come next month "in the pregnancy of moon", i.e., in the time of the moon that now is still an embryo.

All lunar timing is rendered more difficult by the fact that the Bulsa, according to most of my informants, had no traditional, vernacular terms for the sequence of moons. Various attempts have been made to find suitable terms for the twelve English names of the months. Such series of terms usually follow seasonal, ritual and agricultural events; in one extraordinary case, the twelve months are named after the 12 Bulsa chiefs, e.g. wiaga naab chiik," moon of the Wiaga chief"(information from Fumbisi).

Systèmes de Pensée, Cahier 7, 1984 
In the traditional society, definite numbers of months were not combined into larger groups; and the Bulsa never tried to coordinate cycles of the moon and sun, e.g. to count the months of the solaryear and intercalate extra days. Even about the beginning and end of the solar year, the Bulsa provide different information. Although most informants say that in December, after the harvest of the late millet and the fiok festival, the old year has come to its end, two informants stated that the old year ended already in November.

The only lunar unit of time recognized by all Bulsa is the period from the "birth" to the "death" of a moon. For religious or ritual activities, the day of birth has a certain significance. In some areas, people keep certain taboos (kisita, sg. kisuk) on this day. In SandemaKobdem, I was told that, on the "birthday" of a moon, it is forbidden (kisi) to sow millet or to put guinea-fowl eggs under a brooding hen. From other informants, I heard that people should not tell stories in the night of a new moon.

Whenever the birth of a child coincides. with the birth of the new moon, people presume there is a close connection between moon and child, the negative effects of which must be countered by two ritual precautions. Apart from the other amulets given to a new-bornchild, a string with an iron moon, its horns pointing downwards, is hung around his neck. This amulet can be ordered from a local blacksmith or bought in the market. The iron moons for sale are all equipped wi th a short fiber string, which, in fact, is not long enough to surround the baby's neck. A moon pendant should never be kept without a string, since it is believed that the real moon is hanging by a rope in the sky. The removal of the string in the iron replica might have negative consequences for its counterpart.

Here is a description of two lunar amulets that differ from the common, simple form. R. Schott (University of Münster) possesses a brass one made for him with the cire perdue technique by a smith from Sandema-Choabisa. It consist of a brass disc surrounded by a gear-like rim with 29 teeth. Though no further information was given by the smith, the 29 teeth may symbolize the 29 days of the lunar cycle. In the centre of the disc is a small spiral applied with the wax-thread technique. I have another amulet consisting of a rectangular brass plate divided into two equal parts by a thin relief band. This medial line represents the rope on which the moon hangs; it divides the rectangular sky into two equal parts. Exactly below the medial line, outside the rectangle but fixed to it, is the moon with its horns pointing downwards. At the junction of the moon and rectangle is a spiral similar to the one on R. Schott's amulet. I do not knwow whether these two moon pendants were worn by children born on the day of a new moon.

As a second precaution against the negative consequences of their connection with the moon, these children, as soon as they are able to talk, are made to perform a ritual called pobsika on the flat roof of a house. The child faces the moon and blows towards it white ashes taken from the fire-place (if a boy, 3 times; if a girl, 4 times). According to an informant from Sandema-Abilyeri, who had to perform this ritual every month, the following words are spoken three or four times whileblowing, "Chitka abaling bo, N: N. a bii-yo" ("The moon gets thinner - wanes N. N. should get fatter"). According to information from SandemaKobden, the child says three or four times : "N pienti fu" ("I have revealed you", I have found your secret). If the pobsika is not performed every month, the child will stay thin and faint or may break 
out in a rash (see Kröger 1978:59). As soon as the person has grown up, the ceremony of blowing ashes may be stopped.

The pobsika ritual demonstrates an association between the moon and certain persons. Another, much vaguer association can be shown by means of a linguistic-semantic analysis of two terms. In Buli, "moon", chiik, p1. chiisa, is a homophone - also as regards tone - with "soul", chiik, p1. chiisa. Chiik is the human soul that is closely connected to the body and its health but can leave the body in the night while the person is dreaming. After a person's funeral, his chiik-soul wanders to the "Iand of the dead" (kpilung), which can be precisely located for each Bulsa lineage. There, it will meet the souls (chiisa) of deceased members of the lineage. The linguistic correspondence between chiik, moon, and chiik, soul, may be a coincidence. It would not have been mentionned had some further arguments not come to bear.

A parallel to another constituent of the human personality can be established. The wen of a living person is regarded by the Bulsa as a divine power that, from outside his human body, can exert great influence upon him an be positively influenced through sacrifices. The term wen is also used for the sun. A substantial connection between the personal wen and the sun has been proved : in a ceremony called wen-piipika, the wen of a human being descends from the sun (wen) into a special stone in a clay ball held by the concerned individual. From that day on, the stone receives sacrifices offered by the owner of the wen (see Kröger 1978:146-156). Such a clear relationship as this cannot be established between the chilk-soul and the moon, but another Bulsa belief lends support to our hypothesis. The Buli word for star is chi-ngmanik (chi<chiik), which litterally means "cut from the moon". Behind this term may be the idea that the stars emerged from the disintegration of the moon into millions of small particles. The Bulsa associate a falling star with the death of someone, usually a great man. They believe that the star falls into the land of the dead (kpilung) to which the person's (chiik) wanders after the funeral.

Although a connection between chiik (chi-ngmarik), the celestial body, and the chiik-soul can thus be established, further research, also among neighbouring people, should be undertaken in order to determine whether the relations indicated herein exist or whether they are due to an accidental homophony.

\section{References}

Kröger Franz, 1978 : Ubergangsmiten im Wande 2. Kindheit, Feife und Heirat bei den BuZsa in Nord-Ghana. (Kulturanthropologische Studien, ed. R. Schott ana G. Wiegelmann, vo1.1), Klaus Renner Verlag, Hohenschäftlarn near München.

---, 1982 : Ancestor Worship among the Bulsa of Horthem Ghana. ReZigious, Social and Economic Aspects. (Kulturanthropologische Studien, ed. R. Schott and G. Wiegelmann, vo1 9), Klaus Renner Verlag, Hohenschäftlarn near München.

Schott, Rüdiger, 1966/67 : Unpublished fieldnotes. 